\title{
Öğretmenlerde Bireysel İnovasyon ile Öz Liderlik Arasındaki İlişski
}

\author{
The Relationship Between Individual Innovation and Self Leadership in Teachers
}

\section{Mustafa FIDAN}

Doktorant, Ögretmen - Özel Acar Okullart, gfidanmustafa@gmail.com https://orcid.org/0000-0001-7461-4994
Makale Başvuru Tarihi: 19.12.2019

Makale Kabul Tarihi: 30.12.2019

Makale Türü: Araştırma Makalesi

\section{ÖZET}

Anahtar

Kelimeler:

$\ddot{O} z$ Liderlik,

Bireysel

Inovasyon,

Öğretmen,

Keywords:

Self Leadership,

Individual

Innovation,

Teacher,
Liderlik olgusunun temelinde birey (lider) olduğu gibi, inovasyon olgusunun temelinde de yine birey (girişimci) yer almaktadır. Liderlik kavramının tüm yönleriyle gerçekleşmesi için öncelikli olarak öz liderliğin gerçekleştirilmesi gerekir. Benzer şekilde inovasyon olgusunun beklenen mucizeyi gerçekleştirebilmesi için bireysel inovasyon gereklidir. Bu araştırmanın amacı öğretmenlerin bireysel inovasyon ve öz liderlik düzeyleri arasındaki ilişkisinin belirlenmesidir. Araştırma Ankara ili Yenimahalle ilçesi ortaöğretim kurumlarında 2018-2019 eğitim öğretim yılında görev yapan öğretmenlerden tabakalı örneklem alınarak uygulanmıştır. Örneklemde yer alan katılımcllara Öz Liderlik Ölçeği ve Bireysel Inovasyon Ölçeği uygulanarak veri toplanmıştır. Veri toplama sürecinde içerik ile uyumlu olarak inovasyon gerçekleştirilmiş, veri toplama aracı çevrimiçi ortamda uygulanmıştır. Çalışma sonucunda katılımcıların öz liderlik ve bireysel inovasyon düzeyleri yüksek olarak belirlenmistir. Ayrıca bireysel inovasyon ile öz liderlik arasında pozitif yönlü, anlamlı ve yüksek bir ilişsi tespit edilmiştir.

\section{ABSTRACT}

The individual (entrepreneur) is at the core of the phenomenon of innovation as well as the individual (the leader) at the basis of the phenomenon of leadership. In order to realize all aspects of the concept of leadership, first of all, self-leadership must be realized. Similarly, individual innovation is necessary for the phenomenon of innovation to achieve the expected miracle. The aim of this study is to determine the relationship between individual innovation and self-leadership levels of teachers. The research was carried out in the high schools of Yenimahalle district of Ankara in the 2018-2019 academic year. Data were collected by the Self-Leadership Scale and Individual Innovation Scale to the participants in the sample. In the data collection process, innovation was carried out in accordance with the content and the data collection tool was implemented online. As a result of the study, the participants' self-leadership and individual innovation levels were found to be high. In addition, there is a positive, significant and high correlation between individual innovation and self-leadership. 


\section{GIRISS}

Değişim ve liderlik birbirinden ayrılamaz. Liderlik tanımlamaları değişim ile bir şekilde iç içe görülürken değişim kavramı da liderlikten bağımsız tanımlandığında eksik kalmaktadır. Değişimin baş döndürücü bir hal aldığı son yıllarda ise tüm kavramlarda olduğu gibi liderlik ve değişim kavramları da çok yönlü değişim halindedirler. Değişim kavramının pozitif yönü, planlı ve sistemliliğini vurgulayan inovasyon (Erdoğan, 2012:9) ise son yılların önemli olgularındandır. Değişim ve liderlik alanları da dâhil olmak üzere inovasyonun girmediği, bu kavramın tartışılmadığı alan neredeyse yok denilebilir. İçinde bulunan çağın getirdiği öngörülemezlik ve hız karşısında inovasyon kavramı yeni ve orijinal çözümler üretme; aynı zamanda kullanışlılık bağlamında önemli açılımlar sağlamaktadır. Öyle ki, yapılan çalışmalarda inovasyon kelimesi okul planlarını etkileyen sihirli bir kelime olarak ifade edilmiştir (Fullan, 2005:203).

İngilizce innovation kavramının Türkçeleşmiş hali olan kavram için Türkçe yazında yenileşim (TDK, 2017), yenilik (Bülbül, 2012), yenilikçilik (Aksay, 2011; Gürkan ve Demiralay, 2017), yaratıcı yenilik (Taşkın, 2016) ve benzeri birçok kavram kullanılmaktadır. Kavramın bir yönüne 1şık tutan bütün bu kullanımlar aslında inovasyonun kapsamına ve önemine ilişkin birer ipucudurlar. İnovasyon kavramı okul bağlamda; yeni fikir, süreç, davranış, teknoloji veya hizmetlerin geliştirilmesi, kabul edilmesi ve uygulanması şeklinde tanımlanabilir (Amaible, 1988:126; Damanpour ve Aravind, 2011:424). Bir başka tanımda ise inovasyon, okullarda yaratıcı fikirler üzerine bina edilen yeni veya önemli ölçüde iyileştirilmiş yapı, süreç, teknoloji, hizmet, düşünce ve uygulamalar olarak ifade edilmiştir (Oslo Kılavuzu, 2005:50).

İnovasyon kavramının temellerine bakıldığında ilk defa Schumpeter $(1911,1934)$ tarafından ele alındığı görülmektedir. Ekonomik gelişmenin kuramına ilişkin çalışmalarında Schumpeter girişimcilik ve yaratıcı yıkımdan söz ederken inovasyon kavramına ulaşmıştır (Sweezy, 1943:95; Basılgan, 2011:29). Schumpeter'e göre kapitalist ekonomik sistemlerin gelişiminde inovatif girişimci kilit unsur olarak öne çıkmaktadır. Dolayısıyla inovasyon kavramının merkezinde girişimci birey yerin yer aldığı ifade edilebilir. Bir anlamda yaratıcı yıkımların sürükleyicisi ve inovasyonun başlatıcısı inovatif bireylerdir.

Birey liderlik kuramlarının da temelinde yer alır. Liderlik kuramları incelendiğinde bireysel, grupsal ve örgütsel olmak üzere üç başlık görülürken bu başlıkların temelinde bireysel liderlik kuramlarının yer aldığı ifade edilmektedir (Lussier ve Achua, 2010:15). Bireysel bağlamı kendi içinde ikiye ayıran Yukl (2010:33) özellikle kişi içi yani öz liderliğe önemli bir rol atfetmektedir. Liderlik kavramını konuşurken temellerin öz liderlik üzerine bina edildiği adı geçen kaynaklarda vurgulanmaktadır.

Öz liderlik ile kişi içi liderlik bağlamı ele alınmaktadır. Kişi içi liderlik bir başka ifade ile kendi kendine liderlik bazı temel noktalarda açıklanmaktadır. Örneğin, liderlerin sahip olduğu özellikler ve değerlerin, liderlik davranışlarına etkisi kişi içi liderlikle alakalıdır. Ayrıca kişinin liderlik becerileri, liderlik davranışlarıyla iliş̧kisi de burada önemlidir. Liderin karar verme süreci ile zaman yönetimi süreçleri kişi içi liderlikle ilgilidir. Öte yandan liderler de bir insandır ve çeşitli rol beklentileri ya da dış etkilere maruz kalabilirler. İşte liderlerin dönütlere nasıl karşılık verdikleri ve deneyimlerinden nasıl faydalandıkları kişi içi liderlik konusudur. Bunlara ek olarak liderlerin öz-yönetim düzeyleri ve kendilerini geliştirme durumları da kişi içi liderlikte önemli birer açıklayıcıdırlar (Yukl, 2010:33).

Ana akım liderlik kuramları liderlik kavramıyla çoğunlukla lider bir bireyin bir takipçi veya izleyen olarak adlandırılan bir başka bireye bir şey yapmasını yani etkileme olgusunun en az iki birey arasında gerçekleşmesini kastetmektedirler. Öz-liderlik ise bireyin kendi kendini etkileme süreci olarak tanımlanabilir (Manz ve Sims, 1980:361; Manz, 1986:586; Manz ve Sims, 1991:18). Öz-liderlik kavramı, temelde kişinin kendini etkilemesi üzerine kurulmuş öz-denetim, öz-yönetim, öz-düzenleme ve öz-motivasyon süreçlerinin tümünü kapsayan bireysel bir liderlik parantezidir (Williams, 1997:141).

Genel olarak liderlik, nelerin ne şekilde yapılması gerektiğini anlamak, bunlar üzerinde anlaşmaya varmak için insanları etkileme ve ortak hedefleri gerçekleştirmek üzere bireysel ve kolektif çabaları kolaylaştırma sürecidir (Yukl, 2010:26). Bir başka tanımda ise liderlik, lider, takipçi, amaç ve bağlam bileşenleri ile ortaya çıkan ve temelinde liderin bulunduğu bir olgudur (Ladkin, 2010:178). Liderlik sürecinde bireylerin öz-liderlik özellikleri geliştikçe, örgütlerin etkililiğine katkı sağlayacağı (Markham ve Markham, 1995:345) ifade edilmektedir. Manz ve Sims (1991) liderlik gelişim süreçlerini öz-liderlik ile temellendirmişler ve başkalarını yönetmek için önce kendini yönetmelisin şeklinde bir vurguya yer vermişlerdir.

Liderlik olgusunun temelinde birey (lider) olduğu gibi, inovasyon olgusunun temelinde de yine birey (girişimci) yer almaktadır. Liderlik kavramının tüm yönleriyle yaşam bulması için öncelikli olarak öz liderliğin 
gerçekleştirilmesi gerekliliği önemlidir. Benzer şekilde inovasyon olgusunun beklenen mucizeyi yaşama sunabilmesi için bireysel inovasyonun önemli olduğu bir gerçektir. Bireysel inovasyon, yeni fikir, süreç, davranış, teknoloji veya hizmetlerin geliştirilmesi, kabul edilmesi ve uygulanması süreçlerinin tamamının başlatıcısı olan girişimci bireyleri gerektirmektedir (Amaible, 1988:126).

Drucker (1985), inovasyon ve girişimcilik adlı eserinde yönetim alanında devrim etkisi yapan bu iki kavramı (liderlik ve inovasyon) birlikte ele almıştır. Schumpeter (1934) inovasyon kavramını girişimci lider üzerine bina etmiştir. Dolayısıyla inovasyonun bireysel yönünü ifade eden bireysel inovasyon ile liderliğin bireysel yönünü ifade eden öz liderlik konularının ortak paydalarının olabileceği düşünülebilir.

\section{2. ÖĞRETMENLERDE BİREYSEL İNOVASYON ILE ÖZ LIDERLİK ARASINDAKİ İLISSKI}

Öğretmen okulun insan kaynağıdır. Okul üzerinde konuşulan her konuda öğretmen faktörü önemle düşünülmelidir. $\mathrm{Bu}$ çalışmada da ele alınan okulun inovasyon ve liderlik konularında öğretmen üzerine yoğunlaşılması temel bir gerekliliktir. Okulun liderlik süreçleri incelenirken öncelikle okulun insan kaynağı olan öğretmenlerin öz liderlik özellikleri ele alınmalıdır. Benzer şekilde okulun inovasyon süreçleri incelenmek ele alınırken o okulda çalışan insan kaynağı olarak öğretmenlerin bireysel inovasyon özelliklerine bakılması gereklidir. Liderliğin temelinde insan faktörü olduğu gibi inovasyonun temelinde de yine insan faktörü yer almaktadır (Lussier ve Achua, 2010:15; Özdemir, 2018:254; Oslo Kılavuzu, 2005:112).

\subsection{Araştırmanın Amacı ve Önemi}

Bu kapsamda bireysel inovasyon ve öz liderlik kavramlarının birbiriyle ilişkisi ve birlikte kullanılabilirliği test edilmeye değer görülmüştür. Alanyazın incelemeleri sonucunda öz liderlik ve bireysel inovasyon ilişkisini inceleyen çeşitli çalışmalar (Carmeli vd., 2006; Curral ve Marques-Quinteiro, 2009; Ziyae ve Heydari, 2016) görülmüştür. Özellikle Scott ve Vruce (1994) tarafından yapılan çalışma sonuçları liderliğin bireysel innovasyonu destekleyen önemli bir değişken olduğu bulgusu vurgulanmıştır. Bireysel inovasyon ve öz liderliğin öğretmenler bağlamında birlikte incelendiği herhangi bir çalışmaya ise alan yazın taramalarında rastlanmamıştır. Dolayısıyla öğretmen katılımcılar üzerinde ilişkisel bir çalışma desenlenerek bireysel inovasyon ve öz liderlik ilişkisi test edilmek istenmiştir.

$\mathrm{Bu}$ bağlamda araştırmanın amacı, öğretmenlerin bireysel inovasyon ve öz liderlik düzeyleri arasındaki ilişkisinin belirlenmesidir. Bu doğrultuda aşağıdaki sorulara yanıt aranmıştır;

- Öğretmenlerin bireysel inovasyon düzeyleri nasıldır?

- Öğretmenlerin öz liderlik düzeyleri nasıldır?

- Öğretmenlerin bireysel inovasyon düzeyleri cinsiyet, eğitim düzeyi, yaş ve kıdem değişkenlerine göre istatistiksel olarak anlamlı fark göstermekte midir?

- Öğretmenlerin öz liderlik düzeyleri cinsiyet, eğitim düzeyi, yaş ve kıdem değişkenlerine göre istatistiksel olarak anlamlı fark göstermekte midir?

- Bireysel inovasyon ve öz liderlik arasında anlamlı bir ilişki var mıdır?

\subsection{Araştırmanın Yöntemi}

Öğretmenlerin bireysel inovasyon ve öz liderlik özellikleri arasındaki ilişkilerin ortaya çıkarılmasının amaçlandığı bu çalışmada, ilişkisel tarama modeli kullanılmıştır. Verilerin analizleri nicel teknikler kullanılarak çözümlenmiş ve rapor edilmiştir.

\subsubsection{Araştırmanın Modeli}

Bu araştırmada, Ankara ili Yenimahalle ilçesi ortaöğretim kurumlarında öğretmenlerin bireysel inovasyon ile öz liderlik düzeyleri ve bu iki değişken arası ilişkinin belirlenmesi amaçlanmıştır. Bir olgunun mevcut haliyle betimlenmesi, tarama deseninin ve iki değişken arası ilişkinin belirlenmeye çalışılması da ilişkisel tarama deseninin kullanılmasını gerektirmektedir (Özdemir, 2018:304). 


\subsubsection{Araştırmanın Evreni ve Örneklemi}

$\mathrm{Bu}$ araştırmanın evreni, Ankara ili Yenimahalle ilçesi ortaöğretim kurumlarında 2018-2019 eğitim öğretim yılında görev yapan öğretmenlerden oluşmaktadır. İl Milli Eğitim Müdürlüğ̈̈ (2018) verilerine göre evrende bulunan ortaöğretim kurumu ve öğretmen sayıları ve yüzdeleri Tablo 1 ile ayrıntılı olarak görülebilir.

Tablo 1. Evrende Yer Alan Ortaöğretim Kurumları ile Öğretmen Frekans ve Yüzdeleri

\begin{tabular}{|c|c|c|c|c|c|c|c|c|}
\hline \multirow{2}{*}{$\begin{array}{c}\text { Liseler } \\
\text { Yenimahalle }\end{array}$} & \multicolumn{3}{|c|}{ Kurum } & \multicolumn{6}{c|}{ Öğretmen } \\
\cline { 2 - 10 } & $\mathrm{f}$ & $\%$ & $\mathrm{f}$ & $\%$ & $\mathrm{f}$ & $\%$ & $\mathrm{f}$ & $\%$ \\
\cline { 2 - 10 } & 30 & 62.5 & 379 & 37,7 & 237 & 37 & 616 & 37.4 \\
\hline Özel lise & 18 & 37.5 & 625 & 62.3 & 404 & 63 & 1029 & 62.6 \\
\hline Resmi lise & 48 & 100 & 1004 & 100 & 641 & 100 & 1645 & 100 \\
\hline Toplam & & & & & & & & \multicolumn{2}{c|}{ Erkek } \\
\hline
\end{tabular}

Tablo 1'de görüldüğü gibi araştırmanın evreni 2018-2019 eğitim öğretim y1lında Ankara ili Yenimahalle ilçesinde bulunan 48 ortaöğretim kurumunda görev yapan 1645 öğretmenden oluşmaktadır. Bütün öğretmenlerin örneklemde temsil edilmeleri amacıyla tabakalı örnekleme yöntemi tercih edilmiştir. Sosyal bilimlerde sıklıkla kullanılan tabakalı örneklem alma yöntemi, evrendeki alt grupların örneklemde temsil edilmelerinin garanti altına alınabildiği bir yöntemdir. Bu yöntemle basit ve yansız bir şekilde örneklem olarak alınan alt örneklemler toplam örneklemi elde etmek üzere birleştirilir (Balc1, 2011). Toplam örneklem büyüklüğünün belirlenmesinde örneklem büyüklükleri tablosundan yararlanılmıştır (Özdemir, 2018). Tabakalı örnekleme yöntemi ile belirlenen örneklem tablo 2 ile verilmiştir.

Tablo 2. Evren ve Örneklem

\begin{tabular}{|c|c|c|c|c|}
\hline \multirow{2}{*}{$\begin{array}{c}\text { Liseler } \\
\text { Yenimahalle }\end{array}$} & \multicolumn{4}{|c|}{ Öğretmen } \\
\cline { 2 - 5 } & $\mathrm{2}$ & $\%$ & $\mathrm{f}$ & $\%$ \\
\cline { 2 - 5 } & $\mathrm{f}$ & \multicolumn{2}{|c|}{ Örneklem } \\
\hline Özel lise & 616 & 37.4 & 103 & 37 \\
\hline Resmi lise & 1029 & 62.6 & 175 & 63 \\
\hline Toplam & 1645 & 100 & 278 & 100 \\
\hline
\end{tabular}

Tablo 2 üzerinden görülebileceği gibi tabakalı örnekleme yöntemi ile evreni temsil edeceği varsayılan 278 öğretmen, “.168” tabaka ağırlığı ile alt tabakalara ayrılmıştır. Buna göre Yenimahalle ilçesinde özel liselerde 103, resmi liselerde ise 175 öğretmen örneklem olarak belirlenmiştir. Belirlenen örneklemde ölçeklerin uygulanması işlemi gerçekleştirilmiştir. Bunun sonucunda araştırmaya katılan öğretmenlerin kişisel değişkenleri ayrıntılı ortaya çıarılmış ve tablo 3 ile verilmiştir. 
Tablo 3. Araştırmaya Katılan Öğretmenlerin Kişisel Değişkenlere Göre Dağılımları

\begin{tabular}{|c|c|c|c|}
\hline \multirow{2}{*}{ Değişken } & & $\mathrm{f}$ & $\%$ \\
\hline \multirow{3}{*}{ Cinsiyet } & Kadın & 186 & 67 \\
\cline { 2 - 4 } & Erkek & 92 & 33 \\
\hline \multirow{4}{*}{ Yaş } & $23-30$ & 46 & 17 \\
\cline { 2 - 4 } & $31-40$ & 89 & 32 \\
\cline { 2 - 4 } & 41 ve üzeri & 143 & 51 \\
\hline \multirow{3}{*}{ Ĕgitim } & Lisans & 189 & 66 \\
\cline { 2 - 4 } & Yüksek lisans & 89 & 34 \\
\hline \multirow{3}{*}{ Kidem } & $1-5$ yıl & 65 & 23 \\
\cline { 2 - 4 } & 5-15 y1l & 92 & 33 \\
\cline { 2 - 4 } & 15 ve üzeri yıl & 121 & 44 \\
\hline
\end{tabular}

Tablo 3'de görüleceği gibi kadın öğretmenler (186) erkek öğretmenlerden (92); 41 ve üzeri yaş aralığ1 öğretmenler (143) diğer yaş gruplarından; lisans mezunu öğretmenler (189) yüksek lisans mezunu öğretmenlerden ve 15 y1l üstü kıdeme sahip öğretmenler diğer öğretmenlerden daha fazla sayıda katılım göstermiştirler.

\subsection{Veri Toplama Araçları}

Anderson ve Prussia (1997) tarafından geliştirilen, Houghton ve Neck (2002) tarafindan doğrulayıcı analiz çalışmaları yapılan ve daha sonra Fidan (2018) tarafından Türkçe’ye uyarlanan Yenilenmiş Öz-Liderlik Ölçeği kullanılmıştır. Öz liderlik ölçeği, davranış odaklı stratejiler, doğal ödül stratejileri ve yapıcı düşünce stratejileri olmak üzere üç boyut otuz beş maddeden meydana gelmektedir. Bireysel inovasyon özelliklerini belirleme amacıyla Hurt vd. (1977) tarafindan geliştirilen, Kılıçer ve Odabaşı (2010) tarafından Türkçe'ye uyarlanan Bireysel İnovasyon Ölçeği kullanılmıştır. Ölçek değişime direnç, fikir önderliği, deneyime açıklık ve risk alma olmak üzere toplam dört ve yirmi maddeden meydana gelmektedir. Inovasyon yazınında birçok ölçek yer almaktadır. $\mathrm{Bu}$ çalışmada kullanılan ölçeğin belirlenme sürecinde inovasyonun bireysel boyutuna yoğunlaşılmıştır. Öz liderlik ölçeği ve alt boyutları ile bireysel inovasyon ölçeği ve alt boyutları birlikte incelenmiş ölçekler bu çerçevede belirlenmiştir. Her iki ölçek için gerekli izinler alındıktan sonra kişisel bilgi formu da eklenerek veri toplama aracı son halini almıştır.

\section{4. İşlem ve Veri Analizi}

$\mathrm{Bu}$ çalışmada araştırma konusu ile uyumlu olarak veri toplama sürecinde inovasyon yapılmıştır. Araştırmada veri toplama işlemi doğrudan okullarda yüz yüze görüşmeler yapılarak gerçekleştirilmiştir. Bu sebeple veri toplama işlemi, veri toplama aracının çevrimiçi ortama dönüştürülmesi inovasyonu ile buluşmuştur. Bu yöntem 2000’li yıllarda bilişim teknolojileri alanındaki tezlerde kullanılmaya başlanmış olup son yıllarda tüm alanlarda kullanılmaktadır.

Çevrimiçi veri toplama yöntemi uygulama avantajları ile araştırmalarda artan bir eğilime sahiptir. En büyük avantaj olarak daha esnek olmaları ve daha çok kişiye ulaşılabilmesini vurgulayan Lefever vd. (2007:580) tarafından, çevrimiçi veri toplama yöntemi bilimsel araştırmalarda teşvik edilmektedir.

Çataloğlu ve Ateşkan (2014) tarafından online veri toplama araçları tanıtılarak, bunların en yaygın ve bilineni olarak çevrimiçi anket formları gösterilmiştir. Bu yöntemin hem güvenli hem de kolay olması en önemli avantaj olarak ifade edilmiştir. Ayrıca çevreye duyarlılık bağlamında kâğıt tasarrufu sağlaması, aynı ortamda veya farklı ortamlarda uygulanabilmesi gibi avantajları ile tercih edilmektedir. 
Bitmiş vd. (2013) tarafından gerçekleştirilen psikolojik dayanıklılık, örgütsel özdeşleşme ve tükenmişlik ilişkisi araştırmasında çevrimiçi veri toplama aracı kullanılmıştır. Ilgili çalışmada 550 kamu çalışanına e-posta ile gönderilen çevrimiçi formun 430 katılımcı tarafından sağlıklı bir şekilde doldurularak \%78 oranında bir geri dönüş elde edilmiştir. Araştırmacılar bu oranı çok yüksek olarak rapor etmişlerdir. Bu sayede sürecin daha hızlı ve görece daha kolay gerçekleştirği vurgulanmaktadır.

Bu çalışmada ise çevrimiçi formları katılımcılara yüz yüze ulaştırma yöntemi izlenmiştir. Öğretmenler odasında mevcut öğretmenlerden bilgisayar veya akıllı telefon üzerinden yapabilme seçeneği duyurulmuştur. Özellikle çevre duyarlılığı, teknolojik okuryazarlık ve teknolojik imkânlar gibi nedenlerle öğretmenlerin bir kısmı özellikle çevrimiçi formu talep etmişlerdir. Gönüllü bir şekilde talep edilen form akıllı telefonları ve bilgisayarlarına gönderilerek katılımcılar tarafından doldurulma işlemi sağlanmıştır.

Çevrimiçi form sağlayıcıları öğretmenlerce doldurulan formları Excel dosyası olarak vermekte ve araştırmacının işini kolaylaştırmaktadır. Çevrimiçi form olarak gelen ölçekler ise SPSS programına aktarılmıştır. Bu şekilde oluşan veri seti SPSS 20.0 kullanılarak çözümlenmiştir. Araştırmadan elden edilen bulgular frekans, aritmetik ortalama, standart sapma, yüzde değerleri, t testi, tek yönlü varyans analizi, Post Hoc testlerinden LSD testi ve Pearson Korelasyon Katsayısı gibi istatistikler kullanılarak analiz edilmiştir. Yapılan analizlerde .05 anlamlılık düzeyi temel alınmıştır.

\section{ARAŞTIRMANIN BULGULARI VE YORUMLANMASI}

Araştırmanın bu bölümünde başliklar halinde bulgulara yer verilmiş, analizlere ait tablolar sunulmuştur. Çalı̧̧manın bulguları "ögrretmenlerin bireysel inovasyon ve öz liderlik düzeyleri" ile "bireysel inovasyon ve öz liderlik ilişkisi" olarak iki ayrı alt başlık altında ele alınacaktır.

\section{1. Öğretmenlerin Bireysel İnovasyon ve Öz Liderlik Düzeyleri}

Araştırmanın birinci alt problemine cevap aramak için katılımcıların bireysel inovasyon ve öz liderlik ölçekleri toplam puanların aritmetik ortalama ve standart sapma değerleri hesaplanmış ve tablo 4 ile verilmiştir.

Tablo 4. Katılımcıların bireysel inovasyon ve öz liderlik ortalamaları

\begin{tabular}{|c|c|c|c|}
\hline Değişken & Katılımcı & Ortalama & Standart sapma \\
\hline Değişime direnç & 278 & 3.01 & 1.02 \\
\hline Fikir önderliği & 278 & 3.98 & 0.79 \\
\hline Deneyime açıklık & 278 & 4.06 & 1.02 \\
\hline Risk alma & 278 & 3.81 & .87 \\
\hline Bireysel inovasyon toplam & 278 & 3.72 & .96 \\
\hline Davranış odaklı stratejiler & 278 & 3,94 & .85 \\
\hline Doğal ödül stratejileri & 278 & 4.01 & .99 \\
\hline Yapıcı düşünce stratejileri & 278 & 3.89 & .82 \\
\hline Öz liderlik toplam & 278 & 3.95 & .91 \\
\hline
\end{tabular}

Tablo 4 ile görülebileceği gibi, katılımcıların bireysel inovasyon düzeyleri yüksek ( $\bar{X}=3.72$ ) çıkmıştır. Bu bulgu Yenice ve Yavaşoğlu (2018) tarafından öğretmen adayları üzerinde yapılan çalışma sonuçları ile uyuşmamaktadır. Benzer şekilde Yılmaz ve Beşkaya (2018) tarafından yapılan çalışma sonuçları da bireysel inovasyon düzeylerinin yüksek olmadığı şeklinde bulgulara sahiptir. Bu iki çalışmada da katılımcılar yeniliklere karşı tedbirli yaklaşmakta ve sorgulayıcı bir tutum takınmaktadırlar. Kurtipek ve Güngör (2019) tarafından 
yapılan çalışma sonuçları ise bu çalışma bulgularına yakın sonuçlara sahiptir. Katılımcılar bu çalışmaya benzer şekilde bireysel inovasyon puanlarında yüksek ortalamalar belirtmişlerdir.

Katılımcıların öz liderlik düzeyleri ise hem alt boyutlarda hem de toplamda benzer şekilde yüksek ( $\bar{X}=3.72)$ çıkmıştır. Garipağaoğlu ve Güloğlu (2015) tarafindan yapılan çalışma sonuçları öz liderlik ortalamalarının benzer şekilde olduğunu göstermektedir. Benzer şekilde Kızrak vd. (2017) tarafindan yapılan çalışma sonuçları da öz liderlik düzeylerinin yüksek olduğu sonucunu rapor etmiştir.

\subsection{Bireysel İnovasyon ve Öz Liderlik İlişskisi}

Öğretmenlerin bireysel inovasyon ve öz liderlik ilişkisi Pearson Korelasyon Katsayısı ile hesaplanmış ve sonuçları Tablo 5 ile verilmiştir.

Tablo 5. Katılımcıların Bireysel İnovasyon ve Öz Liderlik Ilişkisine Yönelik Korelasyon Sonuçları

\begin{tabular}{|c|c|c|c|c|c|c|c|c|c|}
\hline Boyutlar & 1 & 2 & 3 & 4 & 5 & 6 & 7 & 8 & 9 \\
\hline Değişime direnç & 1 & & & & & & & & \\
\hline Fikir önderliği & $.74 *$ & 1 & & & & & & & \\
\hline Deneyime açıklık & $.65^{*}$ & $.82 *$ & 1 & & & & & & \\
\hline Risk alma & $.77^{*}$ & $.88^{*}$ & $82 *$ & 1 & & & & & \\
\hline Bireysel inovasyon toplam & $.80^{*}$ & $.85^{*}$ & $.87^{*}$ & $.91 *$ & 1 & & & & \\
\hline Davranış odaklı stratejiler & $.75^{*}$ & $.86^{*}$ & $.84 *$ & $.83 *$ & $.67 *$ & 1 & & & \\
\hline Doğal ödül stratejileri & $.67 *$ & $.82 *$ & $.89^{*}$ & $.80^{*}$ & $.81^{*}$ & $.87^{*}$ & 1 & & \\
\hline Yapıcı düşünce stratejileri & $.77 *$ & $.73^{*}$ & $.64 *$ & $.69^{*}$ & $.66^{*}$ & $.61^{*}$ & $.65^{*}$ & 1 & \\
\hline Öz liderlik toplam & $72 *$ & $.88^{*}$ & $.89 *$ & $.79^{*}$ & $.75^{*}$ & $.86^{*}$ & $.80^{*}$ & $.82 *$ & 1 \\
\hline
\end{tabular}

Tablo 5 üzerinden okunabileceği üzere, bireysel inovasyon ile öz liderlik arasında pozitif yönlü, anlamlı ve yüksek bir ilişki $(r=.76, p<.01)$ bulunmuştur. Bu bulgu alan yazında yer alan çalışma sonuçları ile örtüşmektedir. Carmeli vd. (2006) tarafından yapılan çalışma sonuçlarında öz liderlik ile bireysel inovasyon ilişkisi belirtilmiştir. Benzer şekilde Scott ve Bruce (1994) tarafindan yapılan çalışma sonuçları da bireysel inovasyon ve öz liderlik ilişkisi bağlamında çalışma sonuçlarını desteklemektedir. Bu ilişki alt boyutlarda da benzer şekilde varlığını göstermektedir. Bireysel inovasyonun eğişime direnç boyutu bağlamında sadece pozitif yönlü anlamlı ve orta düzey ilişki gözlenmiştir. Bu boyutta görülen görece düşük ilişkinin boyutu oluşturan maddelerin ters madde olmasından kaynaklandığı düşünülmektedir. 


\section{SONUÇ}

Çalışma sonucunda katılımcıların öz liderlik ve bireysel inovasyon düzeyleri yüksek olarak belirlenmiştir. Kurtipek ve Güngör (2019) tarafından bireysel inovasyon konusunda yapılan çalışma sonuçlarında bu çalışma bulgularına benzer sonuçlar görülmektedir. Adı geçen çalışmada katılımcılar bireysel inovasyon puanlarında yüksek ortalamalar belirtmişlerdir. Öz liderlik üzerine Garipağaoğlu ve Güloğlu (2015) tarafından yapılan çalışma sonuçları ile Kızrak vd. (2017) tarafından yapılan çalışma sonuçları da bu çalışma sonuçları ile benzerlik göstermektedir. Öz liderlik ölçeği maddeleri genellikle bireylerin kendilerine ilişkin düşünceleri üzerine şekillendiği için katılımcıların yüksek puanlama yaptıkları düşünülmektedir. Bireysel inovasyon maddelerinde ise değişimin doğal olarak bir dirençle karşılaşma beklentisi ve zor bir süreci ifade etmesinden dolayı her zaman yüksek puanlar görülmemektedir. Nitekim Yılmaz ve Beşkaya (2018) tarafından yapılan çalışma sonuçlarında bireysel inovasyon puanları yüksek değildir. Dolayısıyla bireysel inovasyon puanlarının bu çalışmada öğretmen örnekleminde yüksek çıkmış olması olumlu bir şekilde yorumlanabilir.

Ayrıca bireysel inovasyon ile öz liderlik arasında pozitif yönlü, anlamlı ve yüksek bir ilişki tespit edilmiştir. Katılımcılar her iki değişkenin alt boyutlarında ve toplam puanlarında orta ve yüksek ilişki olduğunu ifade etmişlerdir. Bu sonuç alan yazında var olan çalışma bulguları ve kuramsal arka planla uyumludur. Carmeli vd. (2006) ve Scott ve Bruce (1994) tarafından yapılan çalışmaların sonuçları bireysel inovasyon ve öz liderlik arasındaki pozitif, anlamlı ve yüksek ilişkiyle uyumludur. Her iki çalışmada bireysel inovasyon ile öz liderliğin ilişkisi vurgulanmaktadır. Bunun yanında Gümüşlüoğlu ve İlsev (2009:462) tarafından yapılan liderlik yaratıc1lık ve inovasyon konularının ilişkisel incelendiği çalışmada bireysel inovasyon ile liderliğin ilişkisi vurgulanmaktadır. Bu bağlamda elde edilen sonucu bu çalışmada vurgulanan kuramsal çerçeve ile uyumlu olması önemlidir. Dolayısıyla bu çalışma sonuçlarının öğretmenlerde öz liderlik ve bireysel inovasyon özelliklerinin ilişkisi bulgusuyla alan yazına katkı sağlayacağı söylenebilir.

Bu bulgular çerçevesinde çeşitli öneriler sunulabilir;

- $\mathrm{Bu}$ araştırma Ankara ili Yenimahalle ilçesinde yapılmıştır. Benzer çalışmalar diğer ilçelerde de tekrarlanabilir.

- $\mathrm{Bu}$ araştırmada öğretmen katılımcılar yer almıştır. Okul yöneticileri ve diğer paydaşların algılarına yönelik araştırmalar yapılabilir.

- Katılımcıların öz liderlik ve bireysel inovasyon ilişkisi yüksek bulunmuştur. Bu ilişki ileri düzey araştırma teknikleri ile kurgulanan yeni araştırmalarla zenginleştirilebilir.

- Yüksek ortalamaların görüldüğü öz liderlik ve bireysel inovasyon ortalamalarının nedenleri nitel çalışmalarla derinlemesine incelenebilir.

- Öz liderlik ile bireysel inovasyonun ilişkisine yönelik sonuçlar uygulayıcılar ve öğretmenler ile paylaşılabilir. Bu bağlamda çeşitli hizmet içi eğitimler veya çalıştaylar düzenlenebilir. 


\section{KAYNAKLAR}

AKSAY, Kadir (2011), "Yenilikçilik Kültürünün Örgütsel Yenilikçilik Üzerine Etkisi: Konya Ilinde Faaliyet Gösteren Özel Hastanelerde Bir Uygulama", Doktora Tezi, Selçuk Üniversitesi Sosyal Bilimler Enstitüsü, Konya.

AMABILE, Teresa (1996), "The Motivation for Creativity in Organizations", E-Article, http://www.hbs.edu/faculty/Pages/item.aspx?num=13674 (Erişim Tarihi: 03.11.2017).

AMABİLE, Teresa, CONTI, Regina, COON, Heather, LAZENBY, Jeffrey ve HERRON, Michael (1996), "Assessing The Work Environment for Creativity", The Academy of Management Journal, S.39(5), ss.1154-1184.

ANDERSON, Joe ve PRUSSA, Gregory (1997), "The Self-Leadership Questionnaire: Preliminary Assessment of Construct Validity", The Journal of Leadership Studies, S.4, ss.119-143.

BALCI, Ali (2011), Sosyal Bilimlerde Araştırma: Yöntem, Teknik ve Ilkeler, Pegem Yayıncılık, Ankara.

BASILGAN, Müslüm (2011), "Ekonomik Gelişmenin Yaratıcı Yıkımı: Schumpeteryan Girişimci”, Amme İdaresi Dergisi, S.44(3), ss.27-56.

BİTMIŞ, Gökhan, SÖKMEN, Alptekin ve TURGUT, Hakan (2013), "Psikolojik Dayanıklılığın Tükenmişlik Üzerine Etkisi: Örgütsel Öz Değerlendirmenin Aracılık Rolü", Gazi Üniversitesi İktisadi ve İdari Bilimler Fakültesi Dergisi, S.15(2), ss.27-40.

BÜLBÜL, Tuncer (2012), "Developing a Scale for Innovation Management at Schools: a Study of Validity And Reliability”, Educational Sciences: Theory \& Practice, S.12(1), ss.168-174.

BÜYÜKÖZTÜRK, Şener (2011), Sosyal Bilimler Için Veri Analizi Eı Kitabı: İstatistik, Araştırma Deseni, SPSS Uygulamaları ve Yorum, Pegem Akademi Yayınları, Ankara, 14.Baskı.

ÇATALOĞLU, Erdat ve ATEŞKAN, Armağan (2014), "Use of QR Codes in Education With Examples", Elementary Education Online, S.13(1), ss.5-14.

ÇUHADAR, Cem, BÜLBÜL, Tuncer ve ILGAZ, Gökhan (2013), "Exploring of The Relationship Between Individual Innovativeness And Techno-Pedagogical Education Competencies of Pre-Service Teachers", Elementary Education Online, S.12(3), ss.797-807.

DAMANPOUR, Fariborz, ARAVIND, Deepa (2011), "Managerial Innovation: Conceptions, Processes, And Antecedents", Management And Organization Review, S.8(2), ss.423-454.

DRUCKER, Peter (1985), İnovasyon ve Girişimcilik: Uygulama ve İlkeler (Çev. İlker Gülfidan), Optimist Yayınları, İstanbul.

ERDOĞAN, İrfan (2012), Eğitimde Değişim Yönetimi, Pegem Akademi Yayınları, Ankara.

FULLAN, Michael (2005), "The Meaning of Educational Change: A Quarter of A Century of Learning", The Roots of Educational Change (Ed. A. Liberman), Springer, Netherlands, ss.202-216.

GÜMÜŞLÜOĞLU, Lal ve İLSEV Arzu (2009). "Transformational leadership, creativity, and organizational innovation” Journal of Business Research S. 62, ss 461-473

GÜRKAN, Gülay ve DEMİRALAY, Tülay (2017), "Bireysel Yenilikçiliğin Çalışanın Yenilikçi Davranışı Üzerindeki Etkisinde Içsel Motivasyonun Aracılık Etkisi", Journal of Entrepreneurship And Innovation Management, S.6(1), ss.65-90.

HOUGHTON, Jeffery ve NECK, Cristopher (2002), "The Revised Self-Leadership Questionnaire: Testing A Hierarchical Factor Structure for Self-Leadership", Journal of Managerial Psychology, S.17, ss.672691.

KILIÇER, Kerem ve ODABAŞI, Hatice (2010), "Bireysel Yenilikçilik Ölçeği (BYÖ): Türkçeye Uyarlama, Geçerlik ve Güvenirlik Çalışması”, Hacettepe Üniversitesi Eğitim Fakültesi Dergisi, S.38, ss.150-164.

KURTIPEK, Serkan ve GÜNGÖR, Nuri Berk (2019), “Individual Innovation: A Research on Sports Manager Candidates", Journal of Education and Learning, S.8(1), ss.264-272. 
LADKIN, Donna (2010), Rethinking Leadership: A New Look at Old Leadership Questions, Edward Elgar Publishing Limited, Cheltenham.

SAMÚEL, Lefever, MICHAEL, Dal ve ÁSRÚN, Matthíasdóttir (2007), "Online Data Collection in Academic Research: Advantages And Limitations", British Journal of Educational Technology, S.38(4), ss.574582.

MANZ, Charles (1983), The Art of Self-Leadership: Strategies for Personal Effectiveness in Your Life And Work, Prentice-Hall, New Jersey.

MANZ, Charles (1986), "Self-Leadership: Toward An Expanded Theory of Self-Influence Processes in Organizations", Academy of Management Review, S.11, ss.585-600.

MANZ, Charles C. ve SIMS, Henry P. (1980), "Self-Management as A Substitute for Leadership: A Social Learning Perspective", Academy of Management Review, S.5, ss.361-367.

MARKHAM, Steve E. ve MARKHAM, Ina S. (1995), "Self-Management And Self-Leadership Reexamined: A Levels of Analysis Perspective", Leadership Quarterly, S.6, ss.343-359.

OSLO KILAVUZU (2005), "Yenilik Verilerinin Toplanması ve Yorumlanması İçin Veriler", E-Klavuz, http://www.tubitak.gov.tr/tubitak_content_files/BTYPD/kilavuzlar/Oslo_3_TR.pdf (Erişim Tarihi: 03.11.2017).

ÖZDEMİR, Murat (2018), Eğitim Yönetimi: Alanın Temelleri ve Çağdaş Yönelimler, Anı Yayıncılık, Ankara.

SCHUMPETER, Joseph A. (1934), The Theory of Economics Development, Oxford University Press, UK.

SCHUMPETER, Joseph A. (1947), "The Creative Response in Economic History", The Journal of Economic History, S.12(2), ss.149-160.

SCOTT, Susanne G. ve BRUCE, Reginald A. (1994), "Determinants of Innovattve Behavior: A Path Model of Individual Innovatıon in The Workplace", Academy of ManagemenI loumal, S.37(3), ss.580-607.

SWEEZY, Paul (1943), "Professor Schumpeter's Theory of Innovation", The Review of Economic Statistics, S.25(1), ss.93-96.

TDK - TÜRK DİL KURUMU (2017), Büyük Türkçe Sözlük: Güncel Türkçe Sözlük, TDK Yayınlar1, Ankara, http://tdkterim.gov.tr/bts/ (Erişim Tarihi: 03.11.2017).

VAN DE VEN, Andrev H. ve POOLE, M. Scott (1995), "Explaining Development And Change in Organizations", Academy of Management Review, S.20(3), ss.510-540.

WOODMAN, Richard W., SAWYER, John E. ve GRIFFIN, Ricky W. (1993), "Toward A Theory of Organizational Creativity", The Academy of Management Review, S.18(2), ss.293-321.

YENICE, Nilgün ve YAVAŞOĞLU, Neslihan (2018), "Fen Bilgisi Öğretmen Adaylarının Bireysel Yenilikçilik Düzeyleri İle Bireysel Yaratıcılıkları Arasındaki İlişkinin İncelenmesi”, Eğitimde Kuram ve Uygulama, S.14(2), ss.107-128.

YUKL, Gary (2010), Leadership in Organizations, Pearson Education, New Jersey, 7.Bask1. 